University of Nebraska - Lincoln

DigitalCommons@University of Nebraska - Lincoln

5-9-1999

\title{
Identification of Quantitative Trait Loci Affecting Female Reproductive Traits in a Multigeneration Meishan-White Composite Swine Population
}

G. A. Rohrer

USDA-ARS, gary.rohrer@ars.usda.gov

J. J. Ford

USDA-ARS

T. H. Wise

USDA-ARS

J. L. Vallet

USDA-ARS, Jeff.Vallet@ars.usda.gov

R. K. Christenson

USDA-ARS

Follow this and additional works at: https://digitalcommons.unl.edu/usdaarsfacpub

Part of the Agricultural Science Commons

Rohrer, G. A.; Ford, J. J.; Wise, T. H.; Vallet, J. L.; and Christenson, R. K., "Identification of Quantitative Trait Loci Affecting Female Reproductive Traits in a Multigeneration Meishan-White Composite Swine Population" (1999). Publications from USDA-ARS / UNL Faculty. 165.

https://digitalcommons.unl.edu/usdaarsfacpub/165

This Article is brought to you for free and open access by the U.S. Department of Agriculture: Agricultural Research Service, Lincoln, Nebraska at DigitalCommons@University of Nebraska - Lincoln. It has been accepted for inclusion in Publications from USDA-ARS / UNL Faculty by an authorized administrator of DigitalCommons@University of Nebraska - Lincoln. 


\title{
Identification of Quantitative Trait Loci Affecting Female Reproductive Traits in a Multigeneration Meishan-White Composite Swine Population ${ }^{1}$
}

\author{
G. A. Rohrer, J. J. Ford, T. H. Wise, J. L. Vallet, and R. K. Christenson \\ USDA, ARS, U.S. Meat Animal Research Center, Clay Center, NE 68933-0166
}

\begin{abstract}
A multigeneration crossbred Meishan-White composite resource population was used to identify quantitative trait loci (QTL) for age at first estrus (AP) and the components of litter size: ovulation rate (OR; number of ova released in an estrous period) and uterine capacity (UC). The population was established by reciprocally mating Meishan (ME) and White composite (WC) pigs. Resultant $F_{1}$ females were mated to either ME or WC boars to produce backcross progeny (BC) of either $3 / 4$ WC $1 / 4 \mathrm{ME}$ or $1 / 4 \mathrm{WC} 3 / 4 \mathrm{ME}$. To produce the next generation $\left(\mathrm{F}_{3}\right), 3 / 4 \mathrm{WC} 1 / 4 \mathrm{ME}$ animals were mated to $1 / 4$ WC $3 / 4$ ME animals yielding half-blood ( $1 / 2$ WC $1 / 2$ $\mathrm{ME}$ ) progeny. A final generation $\left(\mathrm{F}_{4}\right)$ was produced by inter se mating $F_{3}$ animals. Measurements for $A P$ and $\mathrm{OR}$ were recorded on $101 \mathrm{BC}, 389 \mathrm{~F}_{3}$, and $110 \mathrm{~F}_{4}$ gilts, and UC data were from $101 \mathrm{BC}$ and $110 \mathrm{~F}_{4}$ first parity litters. A genomic scan was conducted with
\end{abstract}

markers ( $n=157$ ) spaced $20 \mathrm{cM}$ apart. All parental, $\mathrm{F}_{1}, \mathrm{BC}$, and $\mathrm{F}_{4}$ animals but only $84 \mathrm{~F}_{3}$ animals were genotyped and included in this study. The QTL analysis fitted a QTL at 1-CM intervals throughout the genome, and QTL effects were tested using approximate genome-wide significance levels. For OR, a significant (E[false positive] <.05) QTL was detected on chromosome 8 , suggestive (E[false positive] <1.0) QTL were detected on chromosomes 3 and 10, and two additional regions were detected that may possess a QTL (E[false positive] <2.0) on chromosomes 9 and 15. Two regions possessed suggestive evidence for QTL affecting AP on chromosomes 1 and 10, and one suggestive region on chromosome 8 was identified for UC. Further analyses of other populations of swine are necessary to determine the extent of allelic variation at the identified QTL.

Key Words: Reproduction, Pigs, Quantitative Traits, Puberty, Ovulation Rate, Uterus

(o1999 American Society of Animal Science All rights reserved.

J. Anim. Sci. 1999. 77:1385-1391

\section{Introduction}

Litter size is one of the most economically important production traits to the swine industry. The ideal gilt reaches puberty at approximately 6 mo of age, farrows a large number of progeny per litter, promptly returns to estrus, and is successfully bred for many parities. However, the heritability of litter size is low (Lamberson, 1990). Christenson et al. (1987) proposed that litter size be partitioned into the component traits of ovulation rate, fertilization rate, embryo survival, and uterine space (Webel and Dziuk, 1974), and proposed a method to estimate uterine capacity. Results of a simulation study revealed that greater response to selection for increased litter size could be achieved if selection were based on ovulation rate and

\footnotetext{
${ }^{1}$ The authors wish to acknowledge the technical assistance of $\mathrm{K}$. Simmerman and S. Hassler for producing and scoring microsatellite genotypes, S. Kluver for manuscript preparation, and the employees of the MARC swine unit for care of the animals.

Received J uly 31, 1998.

Accepted December 7, 1998.
}

uterine capacity than if it were based on litter size (Bennett and Leymaster, 1989). Unfortunately, both traits are difficult to measure.

A marker associated with the estrogen receptor locus (ESR; Short et al., 1997) is currently used in the swine industry, because Rothschild et al. (1996) identified an association between genotypes at this locus and litter size in crossbred pigs containing Chinese and North American breeds. A study to identify quantitative trait loci (QTL) for ovulation rate in swine (Sus scrofa, SSC) by using a genomic scan (Rathje et al., 1997) identified four regions with considerable evidence for QTL segregating on chromosomes $4,8,13$, and 15 . This study utilized a $F_{2}$ population of swine produced by initially mating animals selected for ovulation rate with control animals from the same base population ( $\mathrm{J}$ ohnson et al., 1984). No associations between genetic markers and age at puberty or uterine capacity have been reported in swine. The objective of this study was to identify regions of the genome that contain genes affecting age at puberty, ovulation rate, and uterine capacity. 


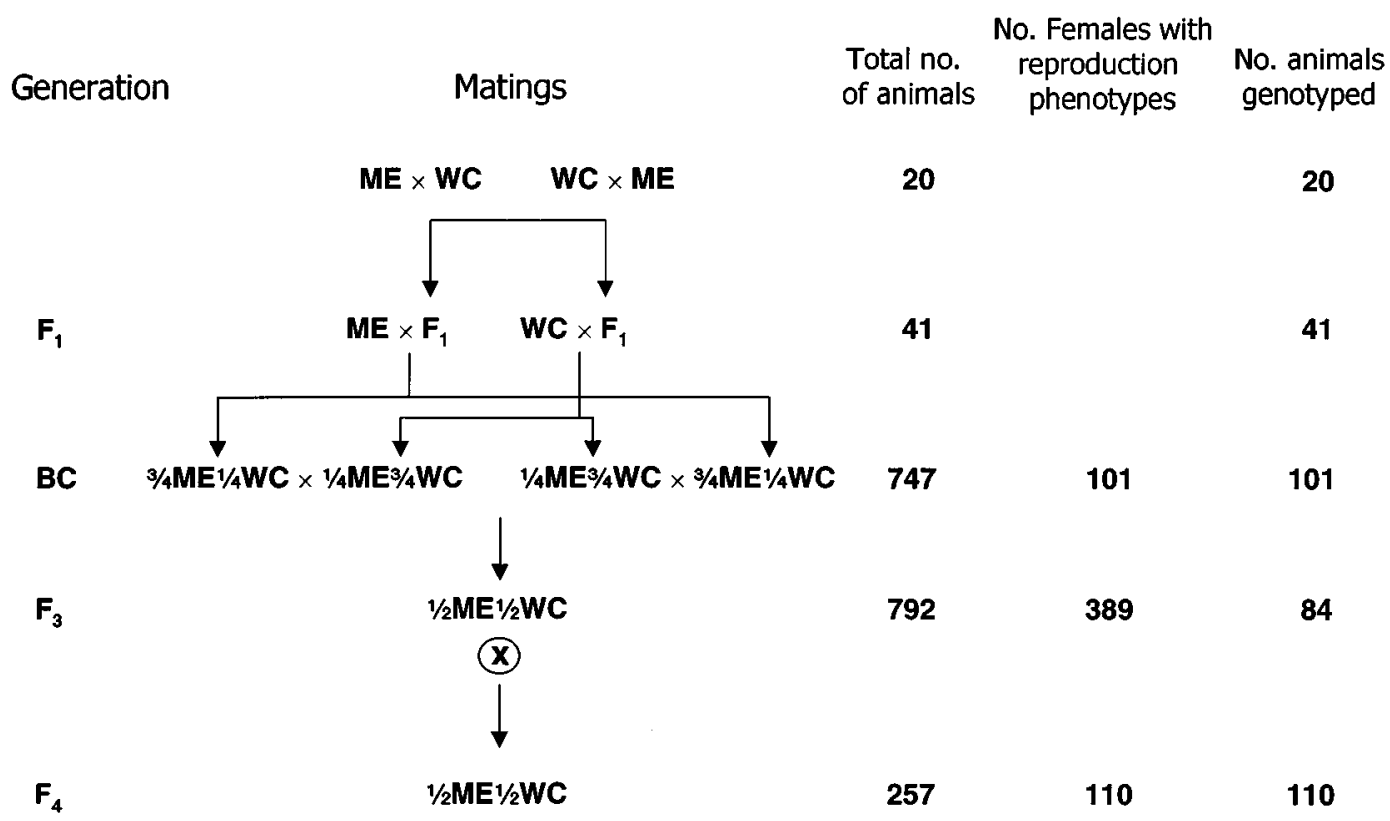

Figure 1. Mating structure of resource population containing Meishan (ME) and White composite (WC) germplasm (the circled times sign represents inter se mating between $\mathrm{F}_{3}$ animals). Breed of sire is listed first in each cross and progeny of reciprocal matings were pooled.

\section{Materials and Methods}

\section{Resource Population}

The resource population was developed from a cross between Meishan (ME) and White composite (WC) swine as diagramed in Figure 1. Five animals of each breed by sex subclass were randomly selected, and reciprocal matings were made to produce 10 litters of $F_{1}$ ME-WC progeny. $F_{1}$ females $(n=41)$ were then mated to either ME or WC boars to produce backcross (BC) progeny of either $3 / 4 \mathrm{ME} 1 / 4 \mathrm{WC}$ or $1 / 4 \mathrm{ME} \mathrm{3/4} \mathrm{WC}$ breed composition. The next generation $\left(\mathbf{F}_{\mathbf{3}}\right)$ was produced by mating $3 / 4 \mathrm{ME} 1 / 4 \mathrm{WC}$ pigs to $1 / 4 \mathrm{ME} 3 / 4 \mathrm{WC}$ pigs using male and female pigs of both breedtypes. The resulting $\mathrm{F}_{3}$ progeny were $1 / 2 \mathrm{ME} 1 / 2 \mathrm{WC}$. The $\mathrm{F}_{3}$ animals were inter se mated to produce an $\mathbf{F}_{\mathbf{4}}$ generation. Phenotypic measurements were collected from $101 \mathrm{BC}, 389 \mathrm{~F}_{3}$, and $110 \mathrm{~F}_{4}$ females, for a total of 600 females phenotyped.

\section{Phenotypic Measurements}

All females were observed daily for evidence of estrus beginning at approximately $100 \mathrm{~d}$ of age with a mature boar. Age at first observed estrus was considered age at puberty (AP). Ovulation rate ( OR) was determined by counting the number of corpora lutea ( CL) present by either laparoscopic observation during gestation (Christenson et al., 1987) or by evaluating the ovaries after slaughter. The BC females $(n=101)$ were mated to produce their first litter at approximately $1 \mathrm{yr}$ of age, and the ovaries were observed via laparoscopic procedures to deter- mine OR at approximately 10 mo of age. Most ( $\mathrm{n}=$ 351) of the $F_{3}$ generation were slaughtered at $d 10$ to 15 of their sixth estrous cycle. Randomly selected $F_{3}$ females $(n=38)$ were retained and bred to produce the $\mathrm{F}_{4}$ generation, and their ovulation rates were determined as in the $\mathrm{BC}$ generation. Ovulation rate data were measured after the fifth estrus and collected either via laparoscopic procedures or after slaughter at approximately $105 \mathrm{~d}$ of gestation in $\mathrm{F}_{4}$ females ( $\mathrm{n}=$ 110).

Females in the $\mathrm{BC}$ and $\mathrm{F}_{4}$ generations were unilaterally hysterectomized and ovariectomized before reaching puberty (Christenson et al., 1987) to permit estimation of uterine capacity. When surgeries were performed, weight and length of the excised uterine horn ( $\mathbf{W}$ and $\mathbf{U L}$, respectively) were recorded along with weight of the removed ovary (OW).

When one ovary is removed, the remaining ovary will compensate by ovulating approximately twice as many ova as normal. Hence, OR is about the same for unilaterally ovariectomized and intact females (Christenson et al., 1987). Thus, in the BC and $F_{4}$ females, developing embryos had only one-half as much uterine space as would be available in an intact female. The crowded uterus can only support a given number of fetuses to term (uterine capacity), and some fetuses are lost during gestation. This permits genetic variation in uterine capacity to be expressed as the number of live animals at birth.

All females in the BC generation and one-fourth of the females in the $\mathrm{F}_{4}$ generation were allowed to farrow. The remainder of the $\mathrm{F}_{4}$ females were 
slaughtered at approximately $105 \mathrm{~d}$ of gestation to measure the number of live, fully-formed fetuses. Uterine capacity ( UC) was defined as the number of live, fully-formed fetuses at the time of slaughter of the pregnant female or at birth of the litter.

\section{Microsatellite Genotypic Data}

Microsatellite markers ( $n=157$ ) were used for the genomic scan. The markers and their multiplex groups were as reported (Rohrer et al., 1997b), with the addition of SW413, which was mapped to the terminal region of chromosome $5 p$ (Rohrer et al., 1997a). All animals in the first three generations and all $F_{4}$ females were genotyped. A selective genotyping approach for females in the $F_{3}$ generation was taken, and only 84 gilts with phenotypes were genotyped. The set of $F_{3}$ animals typed included all females selected (at random) to produce the $\mathrm{F}_{4}$ generation ( $\mathrm{n}$ =33), along with females in litters with the highest and lowest mean values for OR or AP $(n=51)$. For a single trait, the maximum number of selected animals was 33 (AP). Because a majority of the females included in this study were representative of their respective populations (approximately $90 \%$ for OR and $\mathrm{AP}$, and $100 \%$ for all remaining traits), the selective genotyping conducted in the $\mathrm{F}_{3}$ generation should have minimal effects on tests of significance or estimates of genetic effects.

\section{Statistical Analyses for Genome Scan}

The statistical methodology utilized was similar to that reported in Rohrer and Keele (1998a). The CHROMPIC option of CRI-MAP was used to determine grandparental origin of each animal's chromosome. The CHROMPIC information was then analyzed to determine the probability of the breed of origin (Meishan or White composite) at each location across a chromosome (using one centiMorgan intervals). A least-squares regression approach, as described by Haley et al. (1994), was implemented. Nominal probabilities were converted to genome-wide level of significance using the formula presented by Lander and Kruglyak (1995). An approximate value for $\rho(\rho=2.0)$, an autocorrelation coefficient, was used, based on a mean value for each generation, because an exact equation was not presented for experiments with phenotypic data collected in multiple generations. All other parameters were as described (Rohrer and Keele, 1998a).

Fixed effects were fitted for contemporary groups (farrowing season and year), which were confounded with generation and some treatments (intact females vs females with only one ovary). There were two contemporary groups for $B C$ animals, three for $F_{3}$ animals, and only one for $\mathrm{F}_{4}$ animals. A regression coefficient was fitted for percentage of Meishan breed composition (one quarter, half, or three quarters).
Initially, a three degree of freedom test for the QTL genotypic effect was fitted for additive (a), dominance (d), and difference between alternate heterozygotes $(\Delta)$. The contrast fitting $\Delta$ was dropped from the final model when its removal improved the genome-wide significance of the chromosomal region. For QTL regions when $\Delta$ was dropped, a similar test was then used to determine whether $d$ should also be removed. The results presented are for the statistical model that yielded the most significant test at the genome-wide level. Associations with a genome-wide false positive rate of less than 2.0 have been reported because the data set was small. Some of the regions presented that were not at the suggestive level of significance are likely to be false positive associations and should be considered tentative until further analyses are conducted.

\section{Analysis of ESR Locus}

Genotypes were collected for the restriction fragment length polymorphism identified by Rothschild et al. (1996) as described by Short et al. (1997) for females in the $B C$ and $F_{4}$ generations with phenotypic data. Genotypes were categorized in three classes as previously analyzed (Rothschild et al., 1996; Short et al., 1997), and PROC GLM of SAS (1988) was implemented. The model fitted included breed composition and ESR genotype.

\section{Results}

Table 1 presents the information available for all associations identified with a genome-wide rate of false positives less than 2.0. The QTL scan identified associations of six different chromosomes $(1,3,8,9$, 10, and 15) with at least one phenotype. Chromosomes 8 and 10 had multiple associations in different regions. No associations were detected for UW or UL, one association was identified for OW and UC, two for $A P$, and five for OR. Even though the associations did not reach the threshold of 2.0, the analyses of SSC $X$ indicated that a QTL may exist near position $74 \mathrm{cM}$ that affects OR and UC (genome-wide false positive rates of 2.5 and 2.2, respectively).

White composite QTL alleles were superior to Meishan QTL alleles for four out of five regions detected for OR (transgressive variation). The only QTL region for OR for which the Meishan allele was superior to the White composite allele was at SSC 15. Meishan alleles resulted in later AP for the putative QTL at SSC 1 and earlier AP for the putative QTL at SSC 10.

The contrast between alternate heterozygotes was eliminated from analyses of QTL on SSC 3, SSC 8, and SSC 10 for OR and UC (Table 1). For the four associations when the contrast between alternate heterozygotes was eliminated, two were purely addi- 
Table 1. Location, genome-wide level of significance, and genotypic values for statistical associations between chromosomal regions and phenotypic measurements

\begin{tabular}{|c|c|c|c|c|c|c|c|c|c|}
\hline \multirow[b]{2}{*}{ Trait } & \multirow[b]{2}{*}{ Chromosome } & \multirow[b]{2}{*}{ Position $(\mathrm{CM})^{\mathrm{a}}$} & \multicolumn{2}{|c|}{ Degrees of freedom } & \multirow[b]{2}{*}{ F-ratio } & \multirow{2}{*}{$\begin{array}{l}\text { Genome-wide } \\
\text { significance }\end{array}$} & \multicolumn{3}{|c|}{ Genotypic values $^{c}$} \\
\hline & & & Numerator & Denominator & & & a & $d$ & $\Delta$ \\
\hline \multirow{4}{*}{ Ovulation rate } & 8 & $5(-10: 20)$ & 1 & 288 & 26.7136 & .0012 & -2.87 & - & - \\
\hline & 9 & 67 (57:122) & 3 & 286 & 5.7786 & 1.3235 & -1.98 & .10 & -.60 \\
\hline & 10 & 89 (44:118) & 2 & 287 & 7.6215 & .9191 & -2.26 & -1.22 & - \\
\hline & 15 & $79(53: 101)$ & 3 & 286 & 5.7294 & 1.4019 & 2.44 & .25 & -.97 \\
\hline & 10 & $125(115: 134)$ & 3 & 344 & 6.9223 & .3244 & -27.58 & -11.20 & 5.80 \\
\hline Weight of ovary & 8 & 122(116:137) & 3 & 270 & 6.5467 & .5438 & 1.04 & .26 & -.92 \\
\hline Uterine capacity & 8 & $71(53: 107)$ & 2 & 187 & 7.8721 & .8315 & 1.99 & 1.43 & - \\
\hline
\end{tabular}

aposition of the maximum F-ratio based on the map of Rohrer et al. (1996). The range of values in parentheses indicates the 95\% confidence interval of the location of the QTL assuming that the association is real.

${ }^{b}$ Expected number of false positives per genome-wide scan based on Lander and Kruglyak (1995).

CParameters $a$ and $d$ are for the additive effect of an allele substitution and dominance deviations, respectively ( $F$ alconer, 1985). Values for $\Delta$ are the results of the contrast between WC:ME - ME:WC genotypes, where the first symbol indicates the allele inherited from the sire and the second from the dam with $\mathrm{ME}=$ Meishan and $\mathrm{WC}=$ White composite.

tive (SSC 8 for OR and SSC 3 for OR), one seemed to be dominant (SSC 8 for UC), and one was partially dominant (SSC 10 for OR). For five of the nine associations, the contrast between alternate heterozygotes indicated that imprinting may be affecting the phenotype, making it difficult to generalize the type of genetic mechanism displayed. The regions on SSC 1 for AP and SSC 8 for OW had the greatest relative deviations between alternate heterozygotes.

The allele frequencies for the ESR A and B alleles were .472 and .528 , respectively. Genotypic frequencies did not deviate $(P>.05)$ from Hardy-Weinberg equilibrium despite an excess of heterozygotes (as would be expected based on the mating structure of the population). The analyses did not reveal any significant $(P>.20)$ associations of ESR genotypes with any of the phenotypic traits. The association of ESR genotypes with direct measures for the components of litter size were the weakest, with P-values of .93 and .39 for OR and UC, respectively.

\section{Discussion}

Only a few other reports have identified QTL for reproduction in swine. Rathje et al. (1997) reported results from scanning 16 chromosomes in a population created by crossing a line selected for increased ovulation rate with a control line. Wilkie et al. (1996) reported QTL from analyses of eight swine chromosomes in a Meishan $\times$ Yorkshire population. Short et al. (1997) described the results of using a marker for a candidate gene (estrogen receptor) to improve litter size within commercial lines of swine and reported genotypic effects for this marker estimated from over 9,000 females. Unfortunately, the ESR marker of Short et al. (1997) in the present resource population was not associated with variation in either OR or UC (P-values of .93 and .39, respectively), the two components of litter size studied. Table 2 presents a summary of these three reports and any associations nominally significant in the genome scan at these locations in our data.

Reports from several groups looking for reproduction QTL in swine were presented at the 6th World Congress on Genetics Applied to Livestock Production in Armidale, NSW, Australia. Two presentations described scans for most of the genome (Milan et al., 1998; Paszek et al., 1998). Paszek et al. (1998) was a followup of Wilkie et al. (1996), and no additional QTL were identified for traits similar to those studied in our resource population. Milan et al. (1998) looked at 16 chromosomes and found some evidence for QTL affecting reproduction on chromosomes 7 and 8, but it is unclear exactly what traits were affected, along with the level of significance or actual location of each region. Therefore, these references were not included in Table 2. Vincent et al. (1998) reported the results of a candidate gene analysis for a polymorphism located near the prolactin receptor in three distinct swine populations. Unfortunately, their estimates of the additive effects of the $A$ allele fluctuated from -.33 to +.47 pigs per litter, and the mode of gene action was inconsistent. Prolactin receptor has been mapped to porcine chromosome 16 (Vincent et al., 1997).

The present study is the third to identify a QTL for OR on SSC 8; however, the statistical evidence for QTL in each study has been located in different regions of the chromosome. Our maximum test statistic for OR is at the telomeric end of the short arm, data in Rathje et al. (1997) were for the telomeric end of the long arm, and data from the group at the University of Minnesota were for a region near the centromere (Wilkie et al., 1996). Even though we 
Table 2. Genomic regions affecting reproductive traits from the literature and any nominally significant associations among those regions and phenotypic measures in the present data set

\begin{tabular}{|c|c|c|c|c|c|c|}
\hline \multirow[b]{2}{*}{ Trait } & \multicolumn{3}{|c|}{ Reported associations } & \multicolumn{3}{|c|}{ Nominally significant associations in these data } \\
\hline & Chromosome & $\begin{array}{l}\text { Position } \\
(\mathrm{CM})^{\mathrm{a}}\end{array}$ & Reference & $\begin{array}{l}\text { Position } \\
(C M)^{b}\end{array}$ & Trait & $\begin{array}{l}\text { Genome-wide } \\
\text { significance }\end{array}$ \\
\hline \multirow[t]{6}{*}{ Ovulation rate } & 4 & $32(80)$ & Rathje et al. (1997) & 73 & Weight of uterine horn & 6.14 \\
\hline & 8 & 105 & Rathje et al. (1997) & 97 & Uterine capacity & 9.86 \\
\hline & & & & 122 & Weight of ovary & .54 \\
\hline & 8 & $29(50)$ & Wilkie et al. (1996) & 71 & Uterine capacity & .83 \\
\hline & 13 & $0(22)$ & Rathje et al. (1997) & 8 & Weight of ovary & 2.78 \\
\hline & 15 & $51(62)$ & Rathje et al. (1997) & 79 & Ovulation rate & 1.40 \\
\hline \multirow[t]{2}{*}{ Litter size } & 1 & $18^{d}$ & Short et al. (1997) & - & $N S^{e}$ & - \\
\hline & 6 & 134 & Wilkie et al. (1996) & - & NS & - \\
\hline $\begin{array}{l}\text { Length of } \\
\text { uterine horn }\end{array}$ & 8 & $53(57)$ & Wilkie et al. (1996) & 71 & Uterine capacity & .83 \\
\hline
\end{tabular}

were unable to detect QTL for OR at either of the latter two chromosomal regions, the telomeric region of the long arm was associated with variation UC and $\mathrm{OW}$, and the centromeric region was associated with UC in this study (Table 2). Wilkie et al. (1996) also reported a QTL for UL at a position very close to our UC QTL on SSC 8, but their measure of uterine length was from gravid (pregnant) uteri.

It is unlikely that the three QTL regions for OR detected in different populations were produced by the same gene, so it is possible that there are two or three QTL located on SSC 8. This would indicate the importance of SSC 8 for additional mapping. Porcine chromosome 8 has been shown to be homologous to most of human ( Homo sapiens, HSA) chromosome 4 (Goureau et al., 1996). Further comparison reveals the homol ogous sheep (Ovis aries, OAR) chromosome is 6, which includes the Booroola gene (Montgomery et al., 1994). The Booroola allele increases ovulation rate in sheep by 1.25 ova per copy (Davis et al., 1982). The most likely location for the Booroola gene is between the epidermal growth factor (EGF) and osteopontin ( SPP1) genes in sheep (Lord et al., 1996). Based on the comparative map of SSC 8 with HSA 4 (Rohrer, 1999), the porcine homolog to the Booroola gene should be located near the QTL observed by Rathje et al. (1997).

Rathje et al. (1997) reported additional regions on SSC 4, 13, and 15 affecting OR. In this study, the region on SSC 4 was associated with UW and the region on SSC 13 with OW, but neither of these regions were associated with OR (Table 2 ). The only direct overlap between the findings of these two studies was at the QTL for OR on SSC 15. This region is located in an area of SSC 15 homologous to HSA $2 q$ (Goureau et al., 1996). There are no other reports of
QTL affecting swine reproduction traits in this genomic region; however, the Rendement Napole $(\mathbf{R N})$ gene is located in the same region of SSC 15 (Milan et al., 1996). The RN gene affects processed meat yield and quality (Monin and Sellier, 1985), but it is unlikely that this gene affects OR in the populations studied. However, the comparative and fine mapping conducted to identify RN in Europe and the U.S. will benefit the identification of the gene affecting ovulation rate as well.

The region on SSC 1 associated with AP in this study is in the same vicinity as QTL associated with backfat thickness (Rohrer and Keele, 1998a) and loineye area (Rohrer and Keele, 1998b) in the same population. In addition, this same SSC 1 region has been associated with postweaning growth rate in a Y orkshire $\times$ Meishan reference family (Hawken et al., 1998). The current study is the only one that uniquely evaluated differences between alternate heterozygotes, so a comparison of gene action between the effects for backfat thickness, loineye area, growth rate, and AP cannot be made. Estimates of the additive effects for backfat and AP indicate that Meishan alleles produce fatter pigs that reach puberty at a later age. The comparative map would indicate the location of the human homologue for this region is likely to be on HSA 9q (Goureau et al., 1996).

Searches for QTL affecting OR have been reported; however, no other group has published results of genomic scans for AP, UC, UW, and OW traits analyzed in this study. The three measurements of the prepubertal female reproductive tract were recorded because our initial hypothesis was that UC was genetically correlated with UL and OW (Young et al., 1996). Because the correlated characters have higher heritabilities, we expected to identify more QTL for 
these correlated traits than UC. It is interesting to note that nearly as many QTL were identified for UC, the lowly heritable trait, as were identified for the more highly heritable correlated traits such as OW, UW, and UL. Furthermore, the region identified for OW does not overlap any region detected for UC.

Another striking result was the fact that most of the desirable alleles for OR came from the White composite breed. The mean OR for $3 / 4$ Meishan $1 / 4$ White composite pigs in the $\mathrm{BC}$ generation was nearly .7 ova greater than animals of the reciprocal breed type, indicating that, overall, Meishan alleles have greater OR potential than White composite. It is yet to be determined whether additional loci exist for OR with superior Meishan alleles or if epistatic interactions have created the appearance that the Meishan alleles are inferior to the White composite alleles. Meishan alleles for the putative SSC 1 QTL for AP resulted in increased AP, which is also contrary to breed means. Despite the unexpected additive effect for the AP region on SSC 1 (Table 1), its mode of inheritance is unclear and its magnitude is relatively small ( $a=9.35 \mathrm{~d}$ ) compared with the SSC 10 region, which had additive effect of $-27.58 \mathrm{~d}$. Most estimates for genotypic effects on other traits were closer to what would be expected based on breed means.

The performance of alternate heterozygotes differed more often than expected. This may be due to sampling (resource population was not large enough) or may reflect a true genetic phenomenon. It is possible that genomic imprinting is more common than generally believed. Another possible factor would be the presence of epistatic effects. These hypotheses should be adequately tested when additional animals from the $\mathrm{F}_{3}$ generation are genotyped, as well as when other comprehensive studies are reported.

Because this was an initial genome scan, more genotyping needs to be conducted to further resolve the position of the QTL and improve our estimates of the genes' effects. Furthermore, a selective genotyping approach was implemented in the $F_{3}$ generation for $\mathrm{OR}$ and AP. Even though the tests of significance are unaffected by selective genotyping (Stone et al., 1999), the estimates of genotypic effects for the selected traits (OR and AP), as well as any other traits genetically correlated with the selected traits, are biased. However, this bias is only relevant for the genotypic effects associated with OR and AP, because these were the only traits measured in the $F_{3}$ generation. The bias on the estimated effects is expected to be small in magnitude because only $10 \%$ of the data were from animals selected to have extreme phenotypes. Subsequent studies should genotype all animals in populations to produce unbiased estimates of the genotypic effects. Followup studies will either improve the significance level or reveal which identified QTL are false positives. Inclusion of additional phenotyped animals will strengthen the analyses considerably. The analysis of UC conducted for this study included all of the phenotyped animals currently available. Some additional statistical power can be gained by genotyping the animals with additional markers from the identified regions. This procedure should refine the QTL position, but the magnitude of the statistical evidence may not increase. Ultimately, additional animals should be phenotyped if identification of the causative genes is desired.

\section{Implications}

This study represents the first report on mapping quantitative trait loci for both components of litter size (uterine capacity and ovulation rate) using a genome-wide scan. Some of the traits analyzed are impractical for producers to measure, so markerassisted selection may be a more practical approach to be used by the industry. In addition, litter size is one of the most economically important traits to producers and traditional selection results in only marginal improvements. The identified genomic regions for traits affecting litter size need to be examined in commercial swine populations to determine whether allelic variation at the quantitative trait locus exists. Such specific information will significantly help the swine industry develop effective genetic improvement programs for litter size.

\section{Literature Cited}

Bennett, G. L., and K. A. Leymaster. 1989. Integration of ovulation rate, potential embryonic viability and uterine capacity into a model of litter size in swine. J. Anim. Sci. 67:1230-1241.

Christenson, R. K., K. A. Leymaster, and L. D. Young. 1987. J ustification of unilateral hysterectomy-ovariectomy as a model to evaluate uterine capacity in swine. J. Anim. Sci. 65:738-744.

Davis, G. H., G. W. Montgomery, A. J . Allison, R. W. Kelly, and A. R. Bray. 1982. Segregation of a major gene influencing fecundity in progeny of Booroola sheep. N.Z. J . Agric. Res. 25:525-529.

Falconer, D. S. 1985. Introduction to Quantitative Genetics. Second Edition. Longman Inc., New York.

Goureau, A., M. Yerle, A. Schmitz, J . Riquet, D. Milan, P. Pinton, G. Frelat, and J. Gellin. 1996. Human and porcine correspondence of chromosome segments using bidirectional chromosome painting. Genomics 36:252-262.

Haley, C. S., S. A. Knott, and J .-M. Elsen. 1994. Mapping quantitative trait loci in crosses between outbred lines using least squares. Genetics 136:1195-1207.

Hawken, R. J ., A. A. Paszek, P. J . Wilkie, G. W. Flickinger, L. J. Alexander, C. W. Beattie, and L. B. Schook. 1998. Genomic scan for quantitative trait loci influencing growth performance in swine. In: Proc. Plant and Animal Genome VI, San Diego, CA. p 160 (Abstr.).

J ohnson, R. K., D. R. Zimmerman, and R. J . Kittok. 1984. Selection for components of reproduction in swine. Livest. Prod. Sci. 11 541-558.

Lamberson, W. R. 1990. Genetic parameters for reproductive traits. In: L. D. Young (Ed.) Genetics of the Pig. pp 70-76. North Central Regional Research Project NC-103 Report, USMARC, Clay Center, NE, and Univ. of Nebraska, Lincoln. 
Lander, E., and L. Kruglyak. 1995. Genetic dissection of complex traits: Guidelines for interpreting and reporting linkage results. Nat. Genet. 11:241-247.

Lord, E. A., J. M. Lumsden, K. G. Dodds, H. M. Henry, A. M. Crawford, H. A. Ansari, P. D. Pearce, D. W. Maher, R. T. Stone, S. M. Kappes, C. W. Beattie, and G. W. Montgomery. 1996. The linkage map of sheep chromosome 6 compared with orthologous regions in other species. Mamm. Genome 7:373-376.

Milan, D., J . P. Bidanel, P. Le Roy, C. Chevalet, N. Woloszyn, J. C. Caritez, J. Gruand, H. Lagant, M. Bonneau, L. Lefaucheur, C. Renard, M. Vaiman, P. Mormède, C. Désautés, Y. Amigues, F. Bourgeois, J. Gellin, and L. Ollivier. 1998. Current status of QTL detection in Large White $\times$ Meishan crosses in France. Proc. 6th World Congr. Genet. Appl. Livest. Prod. 26:414-417.

Milan, D., N. Woloszyn, M. Yerle, P. Le Roy, M. Bonnet, J. Riquet, Y. Lahbib-Mansais, J .-C. Caritez, A. Robic, P. Sellier, J .-M. Elsen, and J . Gellin. 1996. Accurate mapping of the "acid meat" RN gene on genetic and physical maps of pig chromosome 15 . Mamm. Genome 7:47-51.

Monin, G., and P. Sellier. 1985. Pork of low technological quality with a normal rate of muscles $\mathrm{pH}$ fall in the immediate postmortem period: The case of the Hampshire. Meat Sci. 13:49-63.

Montgomery, G. W., E. A. Lord, J. M. Penty, K. G. Dodds, T. E. Broad, L. Cambridge, S.L.F. Sunden, R. T. Stone, and A. M. Crawford. 1994. The Booroola fecundity ( $F$ ecB) gene maps to sheep chromosome 6. Genomics 22:148-153.

Paszek, A. A., C. W. Beattie, G. W. Flickinger, P. J . Wilkie, and L. B. Schook. 1998. Genomic scan for quantitative trait loci in swine. Proc. 6th World Congr. Genet. Appl. Livest. Prod. 26:418-421.

Rathje, T. A., G. A. Rohrer, and R. K. J ohnson. 1997. Evidence for quantitative trait loci affecting ovulation rate in pigs. J. Anim. Sci. 75:1486-1494.

Rohrer, G. A. 1999. Mapping four genes from human chromosome 4 to porcine chromosome 8 further devel ops the comparative map for an economically important chromosome of the swine genome. Anim. Genet. 30:60-62.

Rohrer, G. A., L. J . Alexander, and C. W. Beattie 1997a. Mapping genes located on human chromosome 2 and 12 to porcine chromosomes 15 and 5. Anim. Genet. 28:448-450.

Rohrer, G. A., L. J . Alexander, Z. H. Hu, T.P.L. Smith, J . W. Keele, and C. W. Beattie. 1996. A comprehensive map of the porcine genome. Genome Res. 6:371-391.

Rohrer, G. A., and J . W. Keele. 1998a. Identification of quantitative trait loci affecting carcass composition in swine: I. Fat deposition traits. J. Anim. Sci. 76:2247-2254.
Rohrer, G. A., and J . W. Keele. 1998b. Identification of quantitative trait loci affecting carcass composition in swine: II. Muscling and wholesale product yield traits. J . Anim. Sci. 76:2255-2262.

Rohrer, G. A., P. Vögeli, G. Stranzinger, L. J . Alexander, and C. W. Beattie. 1997b. Mapping 28 erythrocyte antigen, plasma protein and enzyme polymorphisms using an efficient genomic scan of the porcine genome. Anim. Genet. 28:323-330.

Rothschild, M., C. J acobson, D. Vaske, C. Tuggle, L. Wang, T. Short, G. Eckardt, S. Sasaki, A. Vincent, D. McLaren, O. Southwood, H. van der Steen, A. Mileham, and G. Plastow. 1996. The estrogen receptor locus is associated with a major gene influencing litter size in pigs. Proc. Natl. Acad. Sci. 93:201-205.

SAS. 1988. SAS/STAT User's Guide (Release 6.03). SAS Inst. Inc., Cary, NC.

Short, T. H., M. F. Rothschild, O. I. Southwood, D. G. McLaren, A. de Vries, H. van der Steen, G. R. Eckardt, C. K. Tuggle, J. Helm, D. A. Vaske, A. J. Mileham, and G. S. Plastow. 1997. Effect of the estrogen receptor locus on reproduction and production traits in four commercial pig lines. J . Anim. Sci. 75: 3138-3142.

Stone, R. T., J. W. Keele, S. D. Shackelford, S. M. Kappes, and M. Koohmaraie. 1999. A primary screen of the bovine genome for quantitative trait loci affecting carcass and growth traits. J . Anim. Sci. 77:1379-1384.

Vincent, A. L., G. Evans, T. H. Short, O. I. Southwood, G. S. Plastow, C. K. Tuggle, and M. F. Rothschild. 1998. The prolactin receptor gene is associated with increased litter size in pigs. Proc. 6th World Congr. Genet. Appl. Livest. Prod. 27:15-18.

Vincent, A. M., L. Wang, C. K. Tuggle, A. Robic, and M. Rothschild. 1997. Prolactin receptor maps to pig chromosome 16. Mamm. Genome 8:793-794.

Webel, S. K., and P. J . Dziuk. 1974. Effects of stage of gestation and uterine space on prenatal survival in the pig. J . Anim. Sci. 38: 960-963.

Wilkie, P. J., A. A. Paszek, G. H. Flickinger, G. A. Rohrer, L. J . Alexander, C. W. Beattie, and L. B. Schook. 1996. Scan of eight porcine chromosomes for growth, carcass and reproductive traits reveals two likely quantitative trait loci. Anim. Genet. 27(Suppl. 2):117-118 (Abstr.).

Young, L. D., K. A. Leymaster, and R. K. Christenson. 1996. Opportunities for indirect selection for uterine capacity of swine. J. Anim. Sci. 74(Suppl. 1):119 (Abstr.). 